\title{
MEMBANGUN KEDISIPLINAN SISWA MELALUI AKTIVITAS KEAGAMAAN (Studi Kasus di SMKN 1 Grati Pasuruan Jawa Timur)
}

\author{
M. Ma'ruf \\ Dosen STIT PGRI Pasuruan \\ ahmadm4ruf@gmail.com
}

\begin{abstract}
Abstrak
Tujuan Penelitian ini adalah untuk membantu kepala sekolah dalam membangun dan membina kedisiplinan siswa melalui aktivitas keagamaan di sekolah. Dalam penelitian ini, menggunakan pendekatan Deskriptif Kualitatif dengan jenis penelitian Study Kasus (Case Study). Data dalam penelitian ini didapatkan dari observasi, interview dan dokumentasi. Hasil penelitian menunjukkan aktivitas keagamaan yang dilaksanakan di SMKN 1 Grati Pasuruan membangun kedisiplinan para siswanya sebab dirancang secara sistematis dengan bimbingan, pemberian informasi, pengawasan serta peningkatan kualitas para siswa pada aspek keagamaan, supaya tercipta sikap mental dan pengembangan potensi yang positif sehingga menjadi insan kamil, yakni mempunyai sikap akhlakul karimah dan memiliki keimanan serta ketaqwaan kepada Allah SWT. Dengan adanya kegiatan keagamaan ini, sangat membantu siswa untuk belajar disiplin dalam segala hal mulai dari disiplin masalah ibadah maka dengan begitu bukan masalah ibadah saja yang disiplin tetapi masalah belajar juga ikut disiplin. Adapun Aktivitas keagamaan yang dilaksanakan di SMKN 1 Grati Pasuruan terbagi menjadi tiga tahapan yaitu pertama : aktivitas harian yang terdiri dari shalat dhuha berjama'ah, sholat dhuhur berjama'ah dan program 6 S (Salam, Salim, Senyum, Sapa, Sopan, Santun) yang dilaksanakan setiap hari, kedua : aktivitas mingguan yang terdiri dari shalat jum'at berjama'ah, majlis ta'lim ( khusus untuk siswi perempuan ), dan pembacaan istighasah, dzikir, dan asmaul husna, ketiga : aktivitas pilihan yang terdiri dari ekskul al - banjari, BTQ ( Baca Tulis Qur'an ) dan qiro'ah.
\end{abstract}

Kata kunci : Kedisiplinan Siswa, Aktivitas Keagamaan

\section{Pendahuluan}

Dalam menjalankan ajaran Islam, kedisiplinan sangat diperlukan, sebab banguanan jiwa seseoran akan terbentuk secara teratur, oleh sebab

M. Ma'ruf I 393 
itu pembelajaran kedisiplinan sangat penting untuk perkembangan anak. ${ }^{1}$ Disiplin merupakan bagian dari proses berkelanjutan pengajaran atau pendidikan. $^{2}$

Kedisiplinan mempunyai beberapa unsur yaitu ketaatan, pengetahuan, kesadaran, ketertiban dan perasaan senang dalam melaksanakan tugas dan mematuhi atau mentaati segala peraturanperaturan yang berlaku. Sesungguhnya, kedisplinan merupakan hal yang dapat dilatih melalui penekanan pada aspek pikiran dan watak untuk menghasilkan pengendalian diri, membiasakan patuh dan sebagainya. Dalam proses pembelajaran disebut disiplin. Seorang siswa tidak luput dengan berbagai peraturan dan tata tertib yang ada disekolahnya dalam mengikuti kegiatan belajar di sekolah, dan setiap siswa dituntut untuk dapat berperilaku sesuai dengan aturan tata tertib yang berlaku di sekolahnya. Kepatuhan dan ketaatan siswa terhadap berbagai aturan dan tata tertib yang ada sekolahnya disebut disiplin siswa. Sedangkan peraturan, tata tertib, dan berbagai ketentuan lainnya yang mengatur perilaku siswa disebut disiplin sekolah.

Di lingkungan sekolah, disiplin adalah usaha sekolah untuk memelihara perilaku siswa supaya tidak berperilaku menyimpang dan mendorong para siswa untuk berperilaku sesuai aturan tata tertib di sekolah. Dalam pendisiplinan di sekolah juga diterapkan hukuman atau sanksi sebagai konsekuensi terhadap siswa yang pelanggaran aturan tata tertib sekolah. Menanamkan sikap disiplin pada siswa tidaklah mudah karena melatih siswa berdisiplin sampai benar-benar dapat terealisasi dalam kehidupannya sehari-hari membutuhkan waktu yang lama. Disiplin merupakan perilaku yang memerlukan pembinaan, penanaman melalui proses belajar, dengan demikian perlu ditempuh dengan jalur pelatihan serta jalur keteladanan.

Menanamkan kedisiplinan kepada siswa merupakan bagian dari kelancaran proses belajar mengajar. Oleh karena itu, masalah disiplin perlu mendapat perhatian utama. sehingga para siswa harus mendapatkan bimbingan yang sesuai dan mengembangkan berbagai

${ }^{1}$ Imam Ahmad Ibnu Nazir, Membentuk dan Meningkatkan Disiplin Anak Sejak Dini , (Jogjakarta: Penerbit DIVA Press, 2009), hlm 21.

${ }^{2}$ SiriNam S.Khalsa, Pengajaran \& Disiplin Harga Diri: Strategi, Anekdot, dan Pelajaran Efektif untuk Keberhasilan Manajemen Kelas (Jakarta: Indeks, 2008), hlm 19.

\section{I MEMBANGUN KEDISIPLINAN SISWA MELALUI AKTIVITAS KEAGAMAAN}


kemampuan siswa untuk mencapai tujuan pendidikan dengan disiplin yang baik. Pada lembaga pendidikan seperti sekolah sangat penting adanya peraturan tentang disiplin, sebab dapat mengatur tata hubungan seluruh warga sekolah. Disiplin sekolah mempunyai dua fungsi, yaitu (1) Fungsi yang bermanfaat: (a) untuk mengajarkan kepada siswa bahwa ada perilaku tertentu akan mendapatkan hukuman, namun ada perilaku yang lain akan akan mendapatkan pujian, (b) mengajarkan siswa untuk menyesuaikan dengan wajar, tanpa menuntut konformitas yang berlebihan, (c) membantu siswa untuk mengembangkan pengendalian diri dan pengarahan diri sehingga mereka dapat mengembangkan hati nurani untuk membimbing tindakan mereka. (2) Fungsi yang tidak bermanfaat: (a) menakut-nakuti siswa, dan (b) sebagai pelampiasan agresi orang yang mendisiplin. $^{3}$

Disiplin sekolah adalah usaha sekolah untuk memelihara perilaku siswa sekaligus mengatur hubungan antara sesama masyarakat sekolah supaya tidak menyimpang dari peraturan, norma, dan tata tertib yang berlaku di sekolah. ${ }^{4}$

Sejalan dengan kedisiplinan, Islam menganjurkan bagi pemeluknya bersikap disiplin, untuk taat dan patuh terhadap peraturan yang telah ditentukan oleh Allah SWT. Disiplin dalam hal ini bukan hanya patuh terhadap aturan tapi juga patuh atau disiplin terhadap waktu. Penulis mengambil contoh yakni shalat, di dalam shalat seseorang di tuntut untuk tepat waktu, jika shalat tidak sesuai waktunya maka shalat tersebut dianggap tidak sah. Dalam puasa juga demikian, jika pada saat berpuasa melanggar apa yang diperintahkan, seperti makan dan minum disiang hari maka puasa seseorang tidak sah. Dari kedua kegiatan tersebut sudah terlihat jelas bahwa Islam mengajarkan kepada pemeluknya untuk berlaku disiplin. Kegiatan tersebut termasuk sebagian kecil, masih banyak kegiatan atau aktivitas keagamaan lain yang menganjurkan seseorang untuk berdisiplin.

Penulis tertarik untuk mengambil lokasi penelitian di SMKN 1 Grati Kabupaten Pasuruan, sebab di SMKN 1 Grati Pasuruan kegiatan keagamaannya lebih banyak dari Sekolah Menengah Atas pada umumnya.

Dalam penelitian ini, peneliti memfokuskan riset, bagaimana pelaksanaan aktivitas keagamaan di SMKN 1 Grati Pasuruan dalam

${ }^{3}$ Ridhahani, Tranformasi Nilai-Nilai Karakter/Akhlak dalam Proses Pembelajaran, (Yogyakarta:LKS, 2013), Cet ke-I, hlm. 91.

${ }^{4}$ Ibid, hlm.92.

M. Ma'ruf I 395 
membangun kedisiplinan siswa ? dan mengapa aktivitas keagamaan dapat membangun kedisiplinan siswa di SMKN 1 Grati Pasuruan?

\section{Pembahasan}

\section{A. Pengertian Kedisiplinan}

Kata kedisiplinan berasal dari kata disiplin yang mendapat tambahan awalan ke- dan akhiran -an (kedisiplinan). Menurut W.J.S. Poerwadarminta, kata kedisiplinan mempunyai makna latihan batin dan watak dengan tujuan segala yang dikerjakannya senantiasa mentaati tata tertib. ${ }^{5}$

Dalam kamus Ilmiah Populer dijelaskan bahwa kedisiplinan adalah ketaatan terhadap aturan atau tata tertib. ${ }^{6}$ Sehingga tercipta sebuah kondisi yang tertib dan teratur. 7 Dengan demikian, kedisiplinan adalah mentaati segala tata tertib baik dalam aspek kehidupan, agama, budaya, pergaulan, sekolah, dan lain-lain. Dalam kata lain, kedisiplinan terbentuk melalui proses dari serangkaian aktivitas-aktivitas induvidu yang mengandung nilai-nilai ketaatan, kesetiaan, keteraturan dan ketertiban yang dilakukan dengan rasa senang hati, bukan karena dipaksa atau terpaksa.

\section{B. Tujuan Kedisiplinan}

Menurut Piet A. Sahertian tujuan kedisiplinan adalah:

a. Menjadikan anak yang memiliki kepribadian yang matang, yang awalnya memilki sifat ketergantungan menjadi tidak ketergantungan.

b. Menciptakan kondisi yang taat terhadap segala peraturan yang ada dengan rasa senang hati tidak dipaksa atau terpaksa dalam proses belajar mengajar. ${ }^{8}$

Dengan demikian, tujuan kedisiplinan berfungsi untuk menolong dan membimbing anak supaya menjadi anak yang memiliki

5 Poerwadarminta, Kamus Umum Bahasa Indonesia, (Jakarta: Balai Pustaka, 1997), hlm. 254.

6 Pius A. Partanto, M. Dahlan Al Barry, Kamus Ilmiah Populer, (Surabaya: Arkola, 2001), hlm. 121.

7 A.S. Moenir, Pendekatan Manusiawi dan Organisasi terhadap Pembinaan Kepegawaian, (Jakarta: PT. Gunung Agung, 1983), hlm. 181.

8 Piet A. Sahertian, Dimensi-Dimensi Administrasi Pendidikan di Sekolah, (Jakarta: Usaha Nasional, 1994), hlm. 122-123.

\section{I MEMBANGUN KEDISIPLINAN SISWA MELALUI AKTIVITAS KEAGAMAAN}


kepribadian yang matang dan meningkatkan mental yang sehat serta bertanggung jawab atas segala perbuatannya.

\section{Kaitan Antara Kedisiplinan Dengan Beribadah}

Kedisiplinan ini, bisa dilatih dengan latihan-latihan. Latihanlatihan itu harus menghasilkan kebiasaan untuk patuh, mengendalikan diri dan sebagainya. Seperti halnya, pada masa Rasulullah SAW mengajarkan kepada para umatnya untuk disiplin melaksanakan perintah Allah SWT dan menjahui larangan-Nya.

Apabila kedisiplinan dikaitkan dengan beribadah kepada Allah SWT, pasti saling berkaitan sebab penerapan kedisiplinan pasti ada dalam ajaran Islam, terutama dalam ibadah shalat fardhu, puasa ramadhan, dan zakat yang mana dalam melaksanakan ibadah tersebut harus mengikuti aturan dan ketentuan dari Allah SWT dan Rasulullah SWA. Seperti pada ibadah shalat fardhu, ajaran kedisiplinan ini bisa terlihat pada cara tabir, rukuk, sujud dan waktu shalat. Sebagaimana sabda Nabi SAW, tentang disiplin dalam shalat.

عَنْ عَبْبِ الله بن مَسْعُود رضي الله عنه قال: " سَأَلْتُ رَسُولَ الله صَلَّى الله عََلَيْهِ

Artinya:

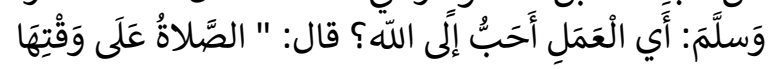

"Dari Abdullah bin Mas'ud r.a. dia berkata: Aku bertanya kepada Rasulullah SAW, perbuatan apa yang paling dicintai oleh Allah? Nabi menjawab, shalatlah tepat pada waktunya shalat... "(HR. Bukhari).

Dalam ajaran Islam diharuskan bagi pemeluknya untuk disiplin dalam berbagai aspek, baik dalam ibadah maupun dalam kehidupan. Sebagaimana firman Allah surat An-Nisa' ayat 103 yang secara implicit menjelaskan kedisiplinan dalam beribadah.

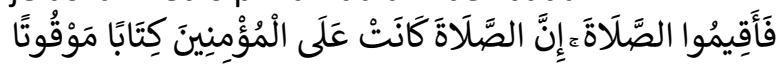

Maka dirikanlah shalat itu (sebagaimana biasa), sesungguhnya shalat itu adalah kewajiban yang ditentukan waktunya atas orangorang beriman. (Q.S. An- Nisa(4):103). ${ }^{9}$

Disebutkan juga perintah taat, patuh dan disiplin dalam surat An-Nisa' ayat 59.

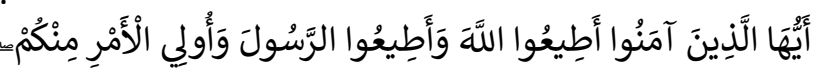

Hai orang-orang yang beriman, taatilah Allah dan taatilah Rasul (Nya), dan ulil amri di antara kamu. (Q.S. An-Nisa'(4): 59). ${ }^{10}$

\footnotetext{
${ }^{9}$ Yayasan Penyelenggara dan Penterjemah Al-Qur'an, Al-Qur'an dan
} Terjemahnya, (Jakarta: Depag. RI, 1989), hlm. 138.

${ }^{10}$ Ibid, hlm. 83 
Hadits dan ayat-ayat di atas menjelaskan untuk disiplin dalam waktu ibadah shalat, metaati perintah Allah Swt, para Rasul dan para pemimpin. Oleh karena itu, semua ajaran Islam seperti shalat, puasa, zakat dan lain sebagainya adalah latihan yang bertujuan untuk menanamkan kedisiplinan yang berguna untuk daya kendali diri seseorang. Orang-orang yang berdisiplin adalah orang yang bisa mengendalikan dirinya. Dengan menciptakan kedisiplinan, maka induvidu, masyarakat dan aparatur pemerintah akan mematuhi segala peraturan dan ketentuan yang ada sehingga tercipta suatu keadaab yang tertib dan teratur.

\section{Pengertian Aktivitas Keagamaan}

Aktivitas keagamaan terdiri dari dua kata, yaitu aktivitas dan keagamaan. Aktivitas artinya kegiatan atau kesibukan. ${ }^{11}$ Dalam artian luas aktivitas dapat diartikan sebagai kegiatan, ucapan ataupun perbuatan yang dilakukan oleh seseorang dalam kehidupan seharihari. Sedangkan keagamaan adalah sifat-sifat yang ada dalam agama atau segala sesuatu yang mengenai agama. ${ }^{12}$ Dapat dikatakan, keagamaan adalah segala sesuatu yang mempunyai sifat-sifat yang ada dalam agama dan yang berhubungan dengan agama. Dengan demikian, aktivitas keagamaan adalah segala perbuatan atau kegiatan yang dilakukan seseorang dalam kehidupan sehari-hari yang berhubungan dengan agama.

Menurut Jalaluddin, aktivitas keagamaan adalah segala aktivitas yang berkaitan dengan keagamaan dalam kehidupan masyarakat dengan menjalankan dan melaksanakan ajaran agama dalam kehidupan sehari-hari. ${ }^{13}$

Dari beberapa definisi di atas dapat peneliti simpulkan bahwa aktivitas keagamaan adalah segala kegiatan yang berhubungan dengan agama, baik berupa kepercayaan ataupun nilai-nilai yang

\footnotetext{
${ }^{11}$ Poerwadarminta, Kamus Umum Bahasa Indonesia..., hlm. 20.

${ }^{12}$ Ibid, hlm. 20

${ }^{13}$ Jalaluddin, Pengantar Ilmu Jiwa Agama, (Jakarta: Kalam Mulia, 1993), hlm. 56
}

398 I MEMBANGUN KEDISIPLINAN SISWA MELALUI AKTIVITAS KEAGAMAAN 
menjadi kebiasaan dan menjadi pedoman dalam berhubungan dengan Allah SWT.

\section{E. Bentuk-bentuk Pembinaan Aktivitas Keagamaan di Sekolah}

Pembinaan aktivitas keagamaan di sini adalah usaha yang dirancang secara sistematis dengan bimbingan, pemberian informasi, pengawasan serta peningkatan kualitas para siswa pada aspek keagamaan, supaya tercipta sikap mental dan pengembangan potensi yang positif sehingga menjadi insan kamil.

Kegiatan keagamaan yang dilaksanakan di sekolah dengan tujuan agar setiap siswanya memiliki sikap akhlakul karimah dan memiliki keimanan serta ketaqwaan kepada Allah SWT. Kegiatan keagamaan yang dilaksanakan sekolah sebagai lembaga yang berkomitmen untuk mengembangkan budaya agama di sekolah yang wajib diikuti oleh seluruh warga sekolah dilaksanakan dalam bentuk:

1) Membaca Al-Qur'an 5 sampai dengan 10 menit sebelum jam pelajaran pertama.

2) Berdo'a secara Islami di awal dan akhir pelajaran.

3) Melaksanakan shalat duhur berjama'ah

4) Membiasakan berinfaq di hari Jum'at

5) Pelaksanaan Perayaan Hari Besar Islam (PHBI)

6) Mengadakan pesantren kilat di bulan Ramadhan

7) Mengadakan kegiatan sosial keagamaan.

8) Memasyarakatkan/membiasakan 3 S (Senyum Salam Sapa)

9) Mengadakan pengajian rutin

10) Mengadakan kegiatan baca tulis/tilawah al-Qur'an.

11) Pakaian sekolah muslim-muslimah pada bulan Ramadhan. ${ }^{14}$

Dilihat dari waktu pelaksanaannya, kegiatan keagamaan di sekolah ada yang dilaksanakan secara rutin baik secara harian, mingguan maupun tahunan. Kegiatan keagamaan yang dilaksanakan setiap hari seperti membaca al-Qur'an selama 5 menit pada jam pelajaran pertama, bersalaman dengan guru sebelum masuk sekolah, sholat Zhuhur berjamaah dan lain sebagainya.

${ }^{14}$ Ermis Suryana dan Maryamah, "Pembinaan Keberagamaan Siswa Melalui Pengembangan Budaya Agama”, Jurnal Ta'dib, Vol. XVIII, No. 02, Edisi November 2013, hlm. 179.

M. Ma'ruf I 399 
F. Pelaksanaan Aktivitas Keagamaan SMKN 1 Grati Pasuruan Dalam Membangun Kedisiplinan Siswa.

Pelaksanaan aktivitas keagamaan di SMKN 1 Grati sudah terstruktur dan di bagi menjadi tiga tahapan yaitu pertama : aktivitas harian yang terdiri dari shalat dhuha berjama'ah, sholat dhuhur berjama'ah dan program $6 \mathrm{~S}$ (Salam, Salim, Senyum, Sapa, Sopan, Santun) yang dilaksanakan setiap hari, kedua : aktivitas mingguan yang terdiri dari shalat jum'at berjama'ah, majlis ta'lim ( khusus untuk siswi perempuan ), dan pembacaan istighasah, dzikir, dan asmaul husna, ketiga : aktivitas pilihan yang terdiri dari ekskul al - banjari, BTQ ( Baca Tulis Qur'an ) dan qiro'ah. ${ }^{15}$

\section{Aktivitas Harian}

a) Shalat Dhuha Berjama'ah

Shalat dhuha merupakan shalat yang dikerjakan pada waktu dhuha yakni, ketika matahari terbit dan menampakkan sinarnya hingga terasa panas sampai menjelang waktu dhuhur. Shalat dhuha ini termasuk amalan istimewa yang dilakukan oleh manusia yang mengharapkan ridho Allah SWT. ${ }^{16}$

Sholat dhuha di SMKN 1 Grati Pasuruan dilaksanakan setiap pagi sekitar jam 9 di masjid sekolah, tidak semua kelas wajib melaksanakan sholat dhuha, tetapi sudah terjadwal setiap harinya kelas apa saja yang wajib melaksanakan shalat dhuha dan yang menjadi imam atau yang mengawasi pada waktu sholat dhuha adalah guru, tetapi meskipun tidak ada guru yang ikut sholat dhuha, pelaksanaan sholat dhuha tetap berjalan dan biasanya yang menjadi imam shalat dhuha adalah seorang siswa dan ketua kelas mengabsen temantemannya yang ikut sholat dhuha. ${ }^{17}$

Dari hasil wawancara dengan guru PAI menyatakan bahwa cara mengevaluasi pelaksanaan shalat dhuha yaitu menggunakan absen siswa yang ikut dan yang tidak ikut melaksanakan sholat dhuha di tulis diabsen dan sangsi yang diberikan dengan sanksi yang mendidik seperti menghafalkan

${ }^{15}$ Observasi pada tanggal 21 Maret 2017

${ }^{16}$ Iqro' al-Firdaus, Dhuha Itu Ajaib!, (Jogjakarta: Diva Press, 2014), hlm. 28

${ }^{17}$ Observasi pada tanggal 21 Maret 2017 
surat-surat pendek. Adapun tujuan dari adanya shalat dhuha supaya siswa terbiasa untuk disiplin dalam beribadah sekaligus untuk menanamkan nilai - nilai ketauhidan kepada mereka. ${ }^{18}$ Ketika seseorang mengerjakan shalat dhuha, maka Allah SWT akan menjamin keamanan kehidupan pada hari itu dan menjahukan dari segala bentuk keburukan. ${ }^{19}$

Adanya shalat dhuha berjama'ah setiap hari juga sesuai dengan misi sekolah SMKN 1 Grati Pasuruan yaitu meningkatkan keimanan dan ketaqwaan kepada Tuhan yang Maha Esa, ${ }^{20}$ akan mudah tercapai.

b) Shalat Dhuhur Berjamaah

Shalat dhuhur berjama'ah tidak diwajibkan, tetapi meskipun tidak diwajibkan rata - rata semua siswa di SMKN 1 Grati mengikuti kegiatan shalat dhuhur berjama'ah, kalau ada siswa yang terlambat untuk mengikuti shalat dhuhur berjama'ah, maka mereka melaksanakan shalat dhuhur berjama'ah pada kloter berikutnya. Adanya shalat dhuhur berjama'ah bertujuan untuk membiasakan siswa SMKN 1 Grati Pasuruan untuk selalu melaksanakan shalat secara berjama'ah. $^{21}$

Dalam ajaran Islam shalat berjamaah itu bisa tegak jika terdapat dua orang, yaitu seorang jadi imam, dan seorang jadi makmu . setiap kali jumlah orang yang mengikuti jamaah bertambah maka semakin bertambah pula cinta kepada Allah SWT. ${ }^{22}$.

Adanya shalat dhuhur berjama'ah dilakukan setiap hari juga sesuai dengan misi sekolah SMKN 1 Grati Pasuruan yaitu meningkatkan keimana dan ketaqwaan kepada Tuhan yang Maha Esa, ${ }^{23}$ akan tercapai.

${ }^{18}$ Wawancara dengan guru PAI bapak Imam Subekti, hari Kamis Tanggal 30 Maret 2017

${ }^{19}$ Pakih Sati, Dahsyatnya Tahajud, Dhuha, Sedekah (TDS), (Surakarta: AlQudwah, 2013), hlm. 56

${ }^{20}$ Sumber data Profil Sekolah SMKN 1 Grati Tahun 2016 - 2017

${ }^{21}$ Wawancara dengan Guru PAI bapak Sajumin, hari Kamis Tanggal 30 Maret 2017

${ }^{22}$ Mu'inudinillah Basri, Bimbingan Shalat Lengkap Sesuai Sunnah, (Solo: Ar Rijal,2014), hlm. 95

${ }^{23}$ Sumber data Profil Sekolah SMKN 1 Grati Tahun 2016 - 2017

M. Ma'ruf | 401 
Shalat merupakan latihan untuk berdisiplin pribadi, dengan melaksanakan shalat pada waktunya akan menumbuhkan kebiasaan untuk melaksanakan secara teratur. Sebab penerapan disiplin dalam kehidupan sehari-hari berawal dari disiplin pribadi. ${ }^{24}$

c) Program $6 \mathrm{~S}$ (Salam, Salim, Senyum, Sapa, Sopan, Santun)

Program 6 S (Salam Salim Senyum Sapa Sopan Santun) dilakukan setiap hari oleh guru piket, jadi tidak semua guru melainkan sudah dibagi perkelompok. Guru yang piket harus datang lebih awal untuk menyambut siswa-siswanya di depan gerbang sekolah dengan Salam Salim Senyum Sapa Sopan Santun. Tidak hanya guru piket tetapi anggota osis juga ikut serta menyambut siswa siswi di depan gerbang sekolah. Anggota osis bertugas mengumumkan berbagai hal kedisiplinan meliputi kelengkapan atribut sekolah, kerapian dan yang membawa sepada motor di ingatkan tentang spion, knalpot yang standart ${ }^{25}$. Tujuan dari $6 \mathrm{~S}$ ( Salam, Salim, Senyum, Sapa, Sopan, Santun ) yaitu untuk pembentukan karakter dimana siswa dilatih untuk disiplin dan bersikap sopan santun apabila bertemu dengan orang yang lebih tua, dengan adanya program tersebut bisa membantu siswa untuk membentuk karakter yang lebih baik sehingga menciptakan siswa yang sopan dan santun. ${ }^{26}$

Pembentukan Akhlakul karimah akan terbentuk melalui proses pendidikan khususnya pendidikan agama. Proses pendidikan ini akan terus berlangsung seumur hidup baik dilingkungan keluarga, sekolah, maupun masyarakat. ${ }^{27}$

Adanya program $6 \mathrm{~S}$ setiap hari oleh guru piket sesuai dengan misi sekolah SMKN 1 Grati Pasuruan yaitu

${ }^{24}$ D. Soemarmo, Pedoman Pelaksanaan Disiplin Nasional dan Tata Tertib Sekolah, (Jakarta: CV. Mini Jaya Abadi, 1997), h. 32.

${ }^{25}$ Observasi pada tanggal 30 Maret 2017

${ }^{26}$ Wawancara dengan Waka Kurikulum ibu Daliyah, hari Jum'at Tanggal 31 Maret 2017

${ }^{27}$ Mahmudi, Pendidikan Karakter: Konsep dan Implementasi, (Bandung: Alfabeta, 2014), hlm. 261

402 I MEMBANGUN KEDISIPLINAN SISWA MELALUI AKTIVITAS KEAGAMAAN 
menciptakan kultur sekolah yang berorientasi pada kultur dunia kerja ${ }^{28}$, akan mudah tercapai.

\section{Aktivitas Mingguan}

a) Shalat Jum'at berjamaah

Sholat Jum'at wajib dilaksanakan oleh siswa tetapi tidak semua siswa diwajibkan mengikuti sholat jum'at di masjid sekolah, dikarenakan masjid SMKN 1 Grati Pasuruan tidak bisa menampung seluruh siswa yang ada. Jadi diberlakukan sistem bergilir setiap shalat Jum'at di jadwalkan ada 3-4 kelas yang wajib melaksanakan sholat Jum'at di sekolah dan total kelas semuanya ada 48 kelas. Sholat Jum'at di sekolah juga boleh di ikuti oleh siswa yang pada saat itu bukan jadwalnya. Jika siswa laki-laki yang sudah terjadwal wajib mengikuti shalat Jum'at berjamaah di masjid sekolah, siswi perempuan yang sudah terjadwal wajib juga mengikuti kegiatan keagamaan kewanitaan yang dilaksanakan di aula sekolah. $^{29}$ Adapun dalam mengevaluasi pelaksanaan shalat jum'at berjama'ah di sekolah ini dengan menggunakan absensi dimana osis memberikan absensi kepada wali kelas yang siswanya yang mendapat giliran jadwal untuk shalat jum'at berjama'ah di sekolah, dan semua siswa yang sudah mengikuti shalat jum'at berjama'ah harus menemui masingmasing wali kelasnya untuk mengisi absen. Apabila ada siswa yang sudah terjadwal tidak mengikuti sholat Jum'at di masjid sekolah maka guru agama memberikan sanksi menulis atau menghafalkan surat-surat pendek. ${ }^{30}$

Adapun tujuan diadakan shalat jum'at berjamaah disekolah untuk menanamkan jiwa kepemimpinan dan kelak bisa digunakan setidak- tidaknya dalam menjadi pemimpin dikeluarganya. Shalat jum'at berjamaah juga bisa membangun kedisiplinan siswa karena siswa dituntut untuk membiasakan melaksanakan kewajiban beribadah dengan tepat waktu terutama ibadah sholat Jum'at. Tujuan lain kenapa diadakan

${ }^{28}$ Sumber data Profil Sekolah SMKN 1 Grati Tahun 2016 - 2017

${ }^{29}$ Observasi pada tanggal 31 Maret 2017

${ }^{30}$ Wawancara dengan guru PAI bapak Imam Subekti, hari Sabtu Tanggal 1 April 2017

M. Ma'ruf | 403 
sholat Jum'at di masjid sekolah karena banyak siswa yang rumahnya jauh sehingga menghindari mereka tidak melaksanakan kewajiban sholat Jum'at. ${ }^{31}$

Dalam hukum Islam diterangkan, setiap laki-laki yang sudah baligh, berakal sehat, merdeka, tidak sedang dalam perjalanan, dan tidak ada halangan, maka ia wajib mendirikan shalat jum'at. ${ }^{32}$ Sebagaimana firman Allah SWT:

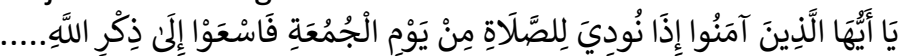
"Hai orang-orang beriman, apabila diseru untuk menunaikan shalat Jum'at, maka bersegeralah kamu kepada mengingat Allah" (QS. Al-Jumuah:9) ${ }^{33}$

Dengan pelaksanaan shalat jum'at disekolah bertujuan juga mendidik siswa supaya terbiasa melakukannya, sehingga tidak gampang meninggalkannya. Sebab orang yang sering meninggalkan shalat jum'at tanpa udzur apapun maka Allah menutup hatinya, sehingga ia sulit mendapatkan petunjuk. Dengan pelaksanaan ini juga siswa akan mendapatkan tambahan ilmu dan pencerahan jiwa dari pesan-pesan khatib jum'ah.

Adanya shalat jum'at berjamaah yang dilaksanakan setiap minggunya sesuai dengan misi sekolah SMKN 1 Grati Pasuruan yang bertujuan untuk meningkatkan keimanan dan ketaqwaan kepada Tuhan yang maha Esa, serta menanamkan jiwa kepemimpinan, ${ }^{34}$ akan mudah tercapai.

b) Majelis Ta'lim (khusus siswi perempuan)

Kegiatan majelis ta'lim sudah terjadwalkan setiap mingguan tetapi tidak semua siswi perempuan mengikuti majelis ta'lim. Majelis ta'lim dilaksanakan ketika siswa laki-laki melakukan shalat jum'at berjamaah, majelis ta'lim bertempat di aula sekolah SMKN 1 Grati Pasuruan, dan yang memberi materi pada majelis ta'lim adalah guru Pendidikan Agama

${ }^{31}$ Wawancara dengan guru PAI bapak Imam Subekti, hari Sabtu Tanggal 1 April 2017

${ }^{32}$ Syekh Ali Ahmad Al-Jarjawi, Indahnya Syariat Islam, (Jakarta: Gema Insani, 2006), hlm. 138

${ }^{33}$ Departemen Agama RI, Al-Qur'an dan Terjemahannya....hlm. 554

${ }^{34}$ Sumber data Profil Sekolah SMKN 1 Grati Tahun 2016 - 2017

\section{I MEMBANGUN KEDISIPLINAN SISWA MELALUI AKTIVITAS}


Islam yang perempuan, dengan adanya majelis ta'lim ini siswi perempuan bisa lebih banyak mengetahui masalah perempuan seperti tentang haid, nifas, wiladah, dan lain sebagainya. Sedangkan bentuk evaluasi kegiatan majelis ta'lim ini, menggunakan absensi, dengan begitu setiap siswi yang hadir dan tidak hadir bisa diketahui dan untuk siswi yang tidak hadir akan dikenakan sangsi berupa membaca surat-surat pendek. $^{35}$

Adanya majlis ta'lim yang dilaksanakan setiap minggu ini sesuai dengan visi sekolah SMKN 1 Grati Pasuruan yang berbunyi terwujudnya tamatan yang berakhlak mulia, ${ }^{36}$ akan mudah tercapai.

c) Pembacaan Istighasah, Dzikir dan Asmaul Husna

Kegiatan istighasah, dzikir dan asmaul husna dilaksanakan setiap hari kamis setelah pulang sekolah bertempat di masjid sekolah SMKN 1 Grati Pasuruan. Kegiatan ini tidak semua siswa siswi boleh ikut tetapi biasanya di utamakan bagi siswa yang banyak kasus di BK. ${ }^{37}$ Adapun tujuan dari kegiatan pembacaan istighasah, dzikir, dan asmaul husna yaitu untuk meningkatkan keimanan dan ketaqwaan siswa kepada Tuhan yang Maha Esa. ${ }^{38}$

Dengan adanya pembacaan Istighasah, dzikir, dan asmaul husna yang dilaksanakan setiap minggunya ini sesuai dengan misi sekolah SMKN 1 Grati Pasuruan yang bertujuan untuk meningkatkan keimanan dan ketaqwaan siswa kepada Tuhan yang Maha $\mathrm{Esa}^{39}$, akan mudah tercapai.

Pembacaan istighasah, dzikir dan asmaul husnal termasuk bentuk do'a kepada Allah SWT yang dilakukan bersama-sama agar semua hajat yang dikehendaki dikabulkan. Dalam ajaran Islam, do'a merupakan ibadah, yang mana

\footnotetext{
${ }^{35}$ Wawancara dengan guru PAI ibu Muthmainah, hari Sabtu Tanggal 2 April 2017

${ }^{36}$ Sumber data Profil Sekolah SMKN 1 Grati Tahun 2016 - 2017

${ }^{37}$ Observasi pada tanggal 6 April 2017

${ }^{38}$ Wawancara dengan guru PAI bapak Imam Subekti, hari Kamis Tanggal 6 April 2017

${ }^{39}$ Sumber data Profil Sekolah SMKN 1 Grati Tahun 2016 - 2017
}

M. Ma'ruf | 405 
EVALUASI. Vol 2. No.2, September 2018 P-ISNN 2580-3387

E-ISSN 2615-2886

seorang hamba memohan pertolongan dan mengharapkan kasih sayang Allah SWT. ${ }^{40}$

\section{Aktivitas Pilihan}

a) Ekskul Al-Banjari

kegiatan al - banjari dilaksanakan setiap hari selasa pukul 15.00 - 16.30 yang bertujuan untuk memvasilitasi siswa dalam mengembangkan potensinya. ${ }^{41}$

Dalam budaya pasti mempunyai nilai-nilai yang bisa diterapkankan dalm kehidupan sehari-hari, salah satunya shalawat Albanjari. Nilai yang dapat diambil dari shalawat Albanjari ini adalah nilai adab yang tercermin dari penampilan pelaku shalawat Albanjari, seperti saling menghormati, sopan dan santun dalam kegiatan sehari-hari. Shalawat Albanjari juga mempunyai nilai kedisiplinan, sebab dalam musik Shalawat Albanjari ada aturan dalam memainkannya, baik pemukul cowok dan cewek ketika reff, yang mana aturanaturan ini bisa diterapkan dalam kehidupan sehari-hari dalam hal kedisiplinan dalm mematuhi peraturan yang ada.

b) Ekskul BTQ (Baca Tulis Al-Qur'an) dan Qiro'ah

Kegiatan ekskul BTQ dan Qiro'ah dilaksanakan setiap hari sabtu pukul $15.00-16.30$, bertempat di mushollah SMKN 1 Grati yang bertujuan untuk memfasilitasi siswa dalam mengembangkan potensinya. ${ }^{42}$

Seorang muslim diharuskan bisa membaca Al-qur'an, sebab Al-qur'an sebagai pedomanan hidup manusia. Allah SWT berjanji akan memberikan petunjuk kepada hambahambanya yang ikhlas menuju kepada-Nya. ${ }^{43}$

\footnotetext{
${ }^{40}$ Muhammad Ismail Ishak, Enskliopedia Do'a dan Szikir, (Jakarta: Alifbata, 2007), hlm.1

${ }^{41}$ Wawancara dengan guru PAI bapak Sajumin, Hari Selasa Tangga 14 April 2017

${ }^{42}$ Wawancara dengan guru PAI bapak Sajumin, Hari Selasa Tangga 14 April 2017

${ }^{43}$ Harun Yahya, Memilih Al-Qur'an sebagai Pembimbing, (Surabaya: Risalah Gusti, 2004), hlm. 60
} 
EVALUASI. Vol 2. No.2, September 2018 P-ISNN 2580-3387

E-ISSN 2615-2886

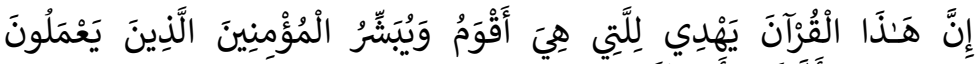

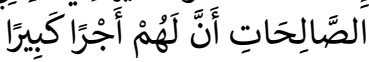

"Sesungguhnya Al Quran ini memberikan petunjuk kepada (jalan) yang lebih lurus dan memberi khabar gembira kepada orang-orang Mu'min yang mengerjakan amal saleh bahwa bagi mereka ada pahala yang besar". (QS. Al-Isra' :9). ${ }^{44}$

Kegiatan membaca Al-Qur'an termasuk bentuk peribadatan untuk mendekatkan diri kepada Allah SWT. Supaya keimanan dan ketaqwaan kita meningkat yang diwujudkan dengan sikap dan prilaku positif. ${ }^{45}$

Berdasarkan fakta yang terdapat di SMK Negeri 1 Grati Pasuruan bahwa aktivitas keagamaan yang ada di SMK Negeri 1 Grati Pasuruan dapat membangun kedisiplinan siswa karena sudah terstruktur secara sistematis berupa bimbingan, pemberian informasi, pengawasan dan juga pengendalian untuk peningkatan kualitas para siswa, sehingga dalam membangun kedisiplinan siswa menjadi lebih mudah untuk proses pelaksanaannya, serta sangat membantu siswa untuk belajar disiplin dalam segala hal mulai dari disiplin masalah ibadah maka dengan begitu bukan masalah ibadah saja yang disiplin tetapi masalah belajar juga ikut disiplin.

Sebagaimana kita ketahui bahwa kedisiplinan dapat dilatih dengan menekankan pada pikiran dan watak untuk menghasilkan kendali diri, kebiasaan untuk patuh dan sebagainya. Latihan-latihan tersebut dalam rangka menghasilkan kebiasaan patuh dalam menanamkan sifat-sifat kedisiplinan. . Karena dengan karakter atau watak itu bisa dibentuk dengan dipaksa, terpaksa dan kemudian terbiasa. Meskipun disiplin pada hakikatnya akan tumbuh dan terpancar dari hasil kesadaran manusia. Sebaliknya, disiplin yang tidak bersumber dari kesadaran hati nurani akan menghasilkan disiplin yang lemah dan tidak akan bertahan lama.

\section{Penutup}

Dalam menjalankan ajaran Islam, kedisiplinan sangat diperlukan, sebab banguanan jiwa seseoran akan terbentuk secara teratur, oleh

${ }^{44}$ Departemen Agama RI, Al-Qur'an dan Terjemahannya....hlm. 283

${ }^{45}$ Asmaun Sahlan, Mewujudkan Budaya Religius di Sekolah (Upaya mengembangkan PAI dari Teori ke Aksi), (Malang: UIN-Maliki Press, 2010), hlm. 120

M. Ma'ruf | 407 
sebab itu pembelajaran kedisiplinan sangat penting untuk perkembangan anak. Menanamkan kedisiplinan pada siswa merupakan bagian dari kelancaran proses belajar mengajar. Oleh karena itu disiplin harus perlu perhatian paling utama. Dengan demikian para siswa harus mendapatkan bimbingan yang sesuai dan mengembangkan berbagai kemampuannya untuk mencapai tujuan pendidikan melalui disiplin yang baik. Pada lembaga pendidikan seperti sekolah sangat penting adanya peraturan tentang disiplin, karena dapat mengatur tata hubungan seluruh warga sekolah.

Dalam hal ini SMK Negeri 1 Grati Pasuruan membangun kedisiplinan para siswanya melalui aktivitas keagamaan yang dirancang secara sistematis dengan bimbingan, pemberian informasi, pengawasan serta peningkatan kualitas para siswa pada aspek keagamaan, supaya tercipta sikap mental dan pengembangan potensi yang positif sehingga menjadi insan kamil, yakni mempunyai sikap akhlakul karimah dan memiliki keimanan serta ketaqwaan kepada Allah SWT. Aktivitas keagamaan yang dilaksanakan di SMKN 1 Grati Pasuruan di bagi menjadi tiga tahapan yaitu pertama : aktivitas harian yang terdiri dari shalat dhuha berjama'ah, sholat dhuhur berjama'ah dan program 6 S (Salam, Salim, Senyum, Sapa, Sopan, Santun) yang dilaksanakan setiap hari, kedua : aktivitas mingguan yang terdiri dari shalat jum'at berjama'ah, majlis ta'lim ( khusus untuk siswi perempuan ), dan pembacaan istighasah, dzikir, dan asmaul husna, ketiga : aktivitas pilihan yang terdiri dari ekskul al - banjari, BTQ ( Baca Tulis Qur'an ) dan qiro'ah.

Aktivitas-aktivitas keagamaan yang ada di SMKN 1 Grati Pasuruan sebagai latihan-latihan dalam rangka menghasilkan kebiasaan patuh dalam menanamkan sifat-sifat kedisiplinan. Karena dengan karakter atau watak itu bisa dibentuk dengan dipaksa, terpaksa dan kemudian terbiasa. Dengan adanya kegiatan keagamaan ini, sangat membantu siswa untuk belajar disiplin dalam segala hal mulai dari disiplin masalah ibadah maka dengan begitu bukan masalah ibadah saja yang disiplin tetapi masalah belajar juga ikut disiplin. Meskipun disiplin pada hakikatnya akan tumbuh dan terpancar dari hasil kesadaran manusia. Sebaliknya, disiplin yang tidak bersumber dari kesadaran hati nurani akan menghasilkan disiplin yang lemah dan tidak akan bertahan lama.

\section{DAFTAR RUJUKAN}

\section{I MEMBANGUN KEDISIPLINAN SISWA MELALUI AKTIVITAS KEAGAMAAN}


Nazir, Imam Ahmad Ibnu. 2009. Membentuk dan Meningkatkan Disiplin Anak Sejak Dini. Jogjakarta: Penerbit DIVA Press.

S.Khalsa, SiriNam. 2008. Pengajaran \& Disiplin Harga Diri: Strategi, Anekdot, dan Pelajaran Efektif untuk Keberhasilan Manajemen Kelas. Jakarta: Indeks.

Ridhahani. 2013. Tranformasi Nilai-Nilai Karakter/Akhlak dalam Proses Pembelajaran. Yogyakarta: LKS.

Poerwadarminta. 1997. Kamus Umum Bahasa Indonesia. Jakarta: Balai Pustaka.

Partanto, Pius A, dan M. Dahlan Al Barry. 2001. Kamus IImiah Populer. Surabaya: Arkola.

A.S. Moenir. 1983. Pendekatan Manusiawi dan Organisasi terhadap Pembinaan Kepegawaian. Jakarta: PT. Gunung Agung.

Sahertian, Piet A. 1994. Dimensi-Dimensi Administrasi Pendidikan di Sekolah. Jakarta: Usaha Nasional.

Yayasan Penyelenggara dan Penterjemah Al-Qur'an.1989. Al-Qur'an dan Terjemahnya. Jakarta: Depag. RI.

Jalaluddin. 1993. Pengantar Ilmu Jiwa Agama. Jakarta: Kalam Mulia.

Suryana, Ermis dan Maryamah. 2013. "Pembinaan Keberagamaan Siswa Melalui Pengembangan Budaya Agama", Jurnal Ta'dib, Vol. XVIII, No. 02, Edisi November.

Iqro' al-Firdaus. 2014. Dhuha Itu Ajaib!. Jogjakarta: Diva Press.

Informan.bapak Imam Subekti. Guru PAI SMKN 1 Grati Pasuruan

Sati, Pakih. 2013. Dahsyatnya Tahajud, Dhuha, Sedekah (TDS). Surakarta: Al-Qudwah.

Sumber data Profil Sekolah SMKN 1 Grati Tahun 2016 - 2017

Informan.bapak bapak Sajumin. Guru PAI SMKN 1 Grati Pasuruan

Basri, Mu'inudinillah. 2014. Bimbingan Shalat Lengkap Sesuai Sunnah. Solo: Ar Rijal

Soemarmo. 1997. Pedoman Pelaksanaan Disiplin Nasional dan Tata Tertib Sekolah. Jakarta: CV. Mini Jaya Abadi. 
EVALUASI. Vol 2. No.2, September 2018 P-ISNN 2580-3387

E-ISSN 2615-2886

Informan. Ibu Daliyah. Waka Kurikulum SMKN 1 Grati Pasuruan

Mahmudi. 2014. Pendidikan Karakter: Konsep dan Implementasi. Bandung: Alfabeta.

Al-Jarjawi, Syekh Ali Ahmad. 2006. Indahnya Syariat Islam. Jakarta: Gema Insani.

Informan. Ibu Muthmainah. Guru PAI SMKN 1 Grati Pasuruan

Ishak, Muhammad Ismail. 2007. Enskliopedia Do'a dan Szikir. Jakarta:

Alifbata.

Yahya, Harun. 2004. Memilih Al-Qur'an sebagai Pembimbing. Surabaya: Risalah Gusti.

Sahlan, Asmaun. 2010. Mewujudkan Budaya Religius di Sekolah (Upaya mengembangkan PAI dari Teori ke Aksi. Malang: UIN-Maliki Press. 